\title{
FAKTOR - FAKTOR YANG MEMPENGARUHI KEPATUHAN IBU DALAM PEMBERIAN IMUNISASI DIFTERI PADA BALITA
}

\author{
Ameylia Hilda Muklati ${ }^{1)}$, Rokhaidah ${ }^{2 *}$ \\ ${ }^{1)}$ Program Studi S1 Keperawatan, Fakultas Ilmu Kesehatan, \\ ${ }^{2)}$ Program Studi DIII Keperawatan, Fakultas Ilmu Kesehatan, \\ Universitas Pembangunan Nasional Veteran Jakarta \\ Kampus II Jl. Raya Limo Depok 16515, Indonesia \\ e-mail: rokhaidah@upnvj.ac.id
}

\begin{abstract}
ABSTRAK
Imunisasi merupakan upaya pencegahan untuk meningkatkan kekebalan seseorang terhadap beberapa penyakit yang dapat dicegah dengan imunisasi (PD3I) khususnya imunisasi Difteria Pertusis Tetanus (DPT). Penelitian ini bertujuan untuk menganalisis hubungan karakteristik (usia ibu, pendidikan ibu, pekerjaan ibu), pengetahuan ibu, sikap ibu, kepercayaan ibu dan dukungan keluarga dengan kepatuhan ibu dalam pemberian imunisasi difteri pada balita. Penelitian ini menggunakan analitik kuantitatif dengan desain Cross-Sectional. Pengambilan sampel menggunakan teknik purposive sampling sehingga didapatkan sampel 75 responden. Responden penelitian adalah ibu yang memiliki balita (usia 1-5 tahun) di RW 01 Kelurahan Kukusan Kecamatan Beji Kota Depok. Instrumen yang digunakan adalah data primer (kuisioner dan observasi) dan data sekunder (buku KMS/KIA). Analisis data yang digunakan yaitu uji statistik bivariat dengan uji Chi-Square. Hasil penelitian terdapat hubungan yang bermakna antara usia ibu $(\mathrm{p}=0,008)$, tingkat pendidikan ibu $(\mathrm{p}=0,000)$, status pekerjaan ibu $(\mathrm{p}=0,003)$, tingkat pengetahuan ibu ( $\mathrm{p}=0,001)$, sikap ibu $(\mathrm{p}=0,001)$, kepercayaan ibu $(\mathrm{p}=0,003)$ dan dukungan keluarga $(\mathrm{p}=0,000)$ dengan kepatuhan ibu dalam pemberian imunisasi difteri pada balita di RW 01 Kelurahan Kukusan Kecamatan Beji Kota Depok. Peneliti merekomendasikan pendidikan kesehatan tentang imunisasi kepada ibu untuk meningkatkan kepatuhan dalam pemberian imunisasi pada anak.
\end{abstract}

Kata Kunci : Difteri; Ibu; Imunisasi; Kepatuhan.

\begin{abstract}
Immunization is prevention efforts to increase a person's immunity to several diseases that can be prevented by immunization (PD3I), specifically Diphtheria Pertusis Tetanus (DPT). This study aims to analyze the relationship of mother's characteristics (age, education, employment), mother's knowledge, maternal attitudes, beliefs of mother and family support with compliance in the provision of diphtheria immunization to toddlers. This study uses quantitative analytics with Cross-Sectional design with a puposive sampling technique and obtained 75 respondents. Respondents this study of a mother having a toddler (aged 1-5 years) in RW 01, Kukusan Village, Beji Sub-District, Depok City. The instruments used are primary data (questionnaire and observation) and secondary data (KMS/KIA books). Analysis of the data used is the bivariate statistical with the Chi-Square method. The results showed that there is a relation between age $(p=0.008)$, education $(p=0,000)$, employment $(p=0.003)$, mother's knowledge $(p=0.001)$, maternal attitudes $(p=0.001)$, beliefs of mother $(p=0.003)$ and family support $(p=0,000)$ with maternal compliance in the provision of diphtheria immunization to toddlers in RW 01 Kukusan Village, Beji Sub-District, Depok City. The researchers recommend health education about immunization to mothers to improve compliance in providing children immunizations.
\end{abstract}

Keywords: Compliance; Diphtheria; Immunization, Mother. 


\section{PENDAHULUAN}

Anak adalah aset berharga suatu bangsa sebagai generasi penerus bangsa, sehingga negara membutuhkan anak-anak yang berkualitas untuk mencapai masa depan bangsa lebih optimal atau terbaik. Berdasarkan UU RI No. 23 Tahun 2003 pasal 1 ayat 1 , anak adalah seseorang yang belum berusia 18 tahun dan termasuk anak yang masih dalam kandungan ibu. Sedangkan menurut WHO, batasan usia anak adalah sejak anak di dalam kandungan hingga usia 19 tahun (Infodatin Kemenkes RI, 2014).

Perbaikan kualitas kesehatan anak dalam Sustainable Development Goals (SDGs) sebagai kesepakatan pembangunan global dari tahun 2015-2030 dengan 17 tujuan dan 169 sasaran. Salah satu tujuan yang menyangkut tentang imunisasi anak yaitu tujuan ketiga yang berisi tentang kesehatan dan kesejahteraan yang baik. Pada tujuan ketiga ini berisi menurunkan angka kematian neonatal hingga 12 per 1000 kelahiran hidup dan angka kematian balita 25 per 1000 kelahiran hidup, mengakhiri epidemi penyakit tropis yang terabaikan dan penyakit menular lainnya (United Nations, 2015).

Penyakit difteri adalah penyakit akibat terjangkitnya bakteri Corynebacterium Diptheriae dan sangat sering menyebabkan kematian. Kematian yang sering terjadi yaitu pada anak-anak yang berusia satu hingga sepuluh tahun (Aprilia dkk., 2018). Penyakit ini juga mudah tertular dan mengenai terutama bagian pernafasan atas (Yunizar \& Hadi, 2018).

Proses penularan penyakit terjadi dari droplet atau lendir, tangan maupun pakaian serta susu yang telah terinfeksi oleh penderita (Aprilia dkk, 2018). Gejala Klinis yang terjadi pada difteri diantaranya demam $\quad>38^{0} \mathrm{C} \quad$ disertai Pseudomembran (selaput tipis) putih keabu-abuan pada tenggorok yang tidak mau lepas dan mudah berdarah di faring, laring dan tonsil, leher membengkak (Bullneck), sakit waktu menelan dan mengalami sesak nafas disertai stridor (Dinkes Kota Depok, 2017). Adapun komplikasi yang 
dapat terjadi yaitu penyempitan sistem nafas, peradangan pada otot jantung, kelumpuhan otot palatum, peradangan telinga tengah dan juga dapat peradangan paru-paru (Hartoyo, 2018).

Imunisasi rutin yang dilakukan dalam pencegahan difteri adalah imunisasi difteri, pertusis dan tetanus. Imunisasi DPT merupakan pemberian vaksin mati sehingga bertujuan dapat memperkuat daya antibodi lebih bertahan diatas ambang preventif serta pemberian imunisasi lebih lengkap juga sangat dibutuhkan (Aprilia dkk., 2018).

Cakupan imunisasi di Indonesia pada anak yang berumur $<24$ bulan menurut imunisasi DPT-Hb3/DPTHb-Hib3 pada tahun 2013 sebesar $75,6 \%$ dan tahun 2018 sebesar $61,3 \%$. Sedangkan proporsi kepemilikan buku KIA pada anak (059 bulan) pada tahun 2013 yaitu $53,4 \%$ dan tahun 2018 yaitu $65,9 \%$ (Riskesdas, 2018).

Fenomena penyakit yang pernah terjadi di Indonesia yaitu penyakit difteri. Berdasarkan hasil World
Health Organization (WHO) Tahun 2013 tercatat India dengan 3.133 kasus difteri, Indonesia dengan 775 kasus difteri dan Pakistan dengan 183 kasus difteri. Tahun 2014 tercatat India dengan 6.094 kasus difteri, Nepal dengan 1.079 kasus diteri dan Indonesia dengan kasus difteri berjumlah 430 kasus. Tahun 2015 tercatat India dengan 2.365 kasus, Madagascar dengan 1.627 kasus difteri dan Indonesia tidak terdapat kasus difteri. Tahun 2016 tercatat India dengan 3380 kasus, Madagascar dengan 2865 kasus dan Indonesia dengan 342 kasus. Sedangkan Tahun 2017 tercatat India dengan 5.293, Indonesia dengan 954 kasus difteri dan Nepal dengan 728 kasus difteri (WHO, 2017).

Profil Kesehatan Indonesia Tahun 2016 terdapat jumlah kejadian difteri yaitu 415 kejadian serta total kematian yaitu 24 kejadian maka CFR Difteri (5,8\%). Disimpulkan bahwa dari data tersebut pada kejadian difteri terbanyak daerah Jawa Timur yaitu 209 kejadian serta Jawa Barat yaitu 133 kejadian (Kemenkes RI, 2016). Sedangkan Tahun 2017, Jumlah kasus difteri 
sebanyak 954 kejadian dengan kematian yaitu 44 kejadian maka CFR Difteri (4,61\%). Disimpulkan bahwa data tersebut pada kejadian difteri terbanyak masih daerah Jawa Timur yaitu 331 kejadian serta Jawa Barat yaitu 167 kejadian.

Cakupan imunisasi DPT-HB3/DPTHB-Hib3 tahun 2015-2017 mengalami penurunan dari tahun 2015 (95\%), tahun 2016 (94\%) dan tahun 2017 (91,89\%). Sedangkan cakupan imunisasi DPT-HB3/DPTHB-Hib3 menurut kecamatan di Kota Depok Tahun 2017 yang tertinggi di Kecamatan Beji sebesar 98,42\% dan yang terendah di Kecamatan Tapos sebesar $82,58 \%$ dan khusus kota depok sebesar 91,89\%. Gambaran kasus difteri di Kota Depok tahun 2016 terdapat 8 kasus kejadian difteri sedangkan tahun 2017 terdapat 4 kasus kejadian difteri (Dinkes Kota Depok, 2017).

Dalam kehidupan sehari-hari, peran orang tua terutama ibu sangatlah penting terhadap kehidupan anaknya. Ibu sangat memerhatikan kesehatan anaknya, biasanya kesehatan anak yang harus diperhatikan adalah program imunisasi. Hal ini dibuktikan dengan banyaknya anak yang terkena penyakit difteri hingga terjadinya kematian. Kemungkinan hal itu terjadi dikarenakan anak yang belum mendapatkan imunisasi dasar lengkap Berdasarkan penelitian (Yuliana \& Sitorus, 2018), faktorfaktor yang mempengaruhi ibu dalam pemberian imunisasi dasar lengkap yaitu pendidikan ibu, pekerjaan ibu, pengetahuan ibu, sikap ibu dan dukungan suami. Menurut penelitian (Senewe, Rompas \& Lolong, 2017), faktor faktor yang berhubungan dengan kepatuhan ibu dalam pemberian imunisasi yaitu support keluarga, dorongan keluarga, sikap, pengetahuan, reaksi/ respon maupun fasilitas kesehatan. Dan menurut penelitian (Chabibah, Hastuti \& Handayani, 2016) bahwa kepercayaan ibu mempengaruhi kepatuhan ibu dalam melakukan imunisasi.

\section{METODE}

Penelitian ini menggunakan analitik kuantitatif dengan desain CrossSectional. Penelitian analitik adalah untuk mencari hubungan antar variabel yang akan diteliti (Dharma, 2011). Desain Cross sectional adalah 
penelitian yang mengamati korelasi diantara independent terhadap dependent, berdasarkan pendekatan atau pengumpulan data yang dilaksanakan secara bersama-sama pada waktu yang sama (Masturoh \& Anggita, 2018). Penelitian ini dilakukan di RW 01 Kelurahan Kukusan Kecamatan Beji Kota Depok. Populasi pada penelitian ini sebanyak 75 ibu yang memiliki balita (usia 1-5 tahun) di RW 01 Kelurahan Kukusan Kecamatan Beji Kota Depok. Sampel pada penelitian ini sebanyak $100 \mathrm{ibu}$ dengan balita (usia 1-5 tahun) di RW 01 Kelurahan Kukusan Kecamatan Beji Kota Depok dengan memakai teknik purposive sampling.

Instrumen penelitian yang digunakan adalah kuisioner dan lembar observasi. Lembar observasi digunakan untuk melihat tanggal pemberian imunisasi DPT-Hb-Hib di Kartu Menuju Sehat (KMS) atau Buku KIA. Sedangkan kuisioner digunakan untuk mengidentifikasi karakteristik responden dan variabel faktor-faktor yang mempengaruhi kepatuhan ibu dalam pemberian imunisasi diferi.

\section{HASIL DAN PEMBAHASAN}

Hasil penelitian terdiri dari identidikasi karakteristik responden dan analisi setiap variabel.

Tabel 1

Karakteristik Responden

\begin{tabular}{|c|c|c|c|}
\hline No & Variabel & & \\
\hline \multirow[t]{3}{*}{1} & Usia & Frekuensi & Persentase \\
\hline & $>35$ tahun & 20 & $26,7 \%$ \\
\hline & $\leq 35$ tahun & 55 & $73,3 \%$ \\
\hline \multirow[t]{3}{*}{2} & Pekerjaan & & \\
\hline & Bekerja & 30 & $40 \%$ \\
\hline & Tidak Bekerja & 45 & $60 \%$ \\
\hline \multirow[t]{3}{*}{3} & Pendidikan & & \\
\hline & $\begin{array}{l}\text { Pendidikan } \\
\text { Rendah }\end{array}$ & 25 & $33,3 \%$ \\
\hline & Pendidikan Tinggi & 50 & $66,7 \%$ \\
\hline \multirow[t]{3}{*}{4} & Pengetahuan & & \\
\hline & $\begin{array}{l}\text { Pengetahuan } \\
\text { Rendah }\end{array}$ & 24 & $32 \%$ \\
\hline & $\begin{array}{l}\text { Pengetahuan } \\
\text { Tinggi }\end{array}$ & 51 & $68 \%$ \\
\hline \multirow[t]{3}{*}{5} & Sikap & & \\
\hline & Negatif & 27 & $36 \%$ \\
\hline & Positif & 48 & $64 \%$ \\
\hline \multirow[t]{3}{*}{6} & Kepercayaan & & \\
\hline & Tidak Percaya & 19 & $25,3 \%$ \\
\hline & Percaya & 56 & $74,7 \%$ \\
\hline \multirow[t]{3}{*}{7} & $\begin{array}{l}\text { Dukungan } \\
\text { Keluarga }\end{array}$ & & \\
\hline & Tidak Mendukung & 27 & $36 \%$ \\
\hline & Mendukung & 48 & $64 \%$ \\
\hline \multirow[t]{3}{*}{8} & Kepatuhan Ibu & & \\
\hline & Tidak Patuh & 16 & $21,3 \%$ \\
\hline & Patuh & 59 & $78,7 \%$ \\
\hline
\end{tabular}

Tabel 2

Hubungan Usia Ibu dengan Kepatuhan Ibu

\begin{tabular}{|c|c|c|c|c|c|c|c|c|}
\hline \multirow{3}{*}{ Usia Ibu } & Tidak & & atuh & & Total & & \multirow{3}{*}{$\begin{array}{c}\mathrm{p}- \\
\text { Value }\end{array}$} & \multirow{2}{*}{$\begin{array}{c}\text { OR } \\
(95 \% \\
\text { CI }) \\
\end{array}$} \\
\hline & \multicolumn{6}{|l|}{ Patuh } & & \\
\hline & $\mathrm{n}$ & $\%$ & $\mathrm{n}$ & $\%$ & $\mathrm{n}$ & $\%$ & & \\
\hline \multirow{2}{*}{$\begin{array}{c}>35 \\
\text { tahun }\end{array}$} & 9 & 56 , & 1 & 18,6 & 2 & 26 , & \multirow{6}{*}{0,008} & 5,610 \\
\hline & & $3 \%$ & 1 & $\%$ & 0 & $7 \%$ & & $(1,71$ \\
\hline$\leq 35$ & 7 & 43 , & 4 & 81,4 & 5 & 73 , & & $5-$ \\
\hline tahun & & $8 \%$ & 8 & $\%$ & 5 & $3 \%$ & & 18,35 \\
\hline \multirow[t]{2}{*}{ Total } & 16 & 100 & 5 & 100 & 7 & 10 & & 5) \\
\hline & & $\%$ & 9 & $\%$ & 5 & $0 \%$ & & \\
\hline
\end{tabular}


Penelitian ini sependapat terhadap penelitian Prihanti, dkk (2016) bahwa ada hubungan antara usia ibu terhadap kelengkapan imunisasi dasar $(p$ value $=0,029)$. Tetapi penelitian ini berlawanan dengan penelitian Chabibah, Hastuti \& Handayani (2016) menyatakan bahwa tidak ada hubungan antara usia ibu dalam melaksanakan imunisasi $(p$ value $=0,751)$.

Penelitian yang sudah dilakukan oleh peneliti menunjukkan bahwa usia 2030 tahun paling banyak ditemukan pada kelompok imunisasi DPT yang patuh yaitu sebesar 42 responden $(85,7 \%)$. Notoatmodjo menjelaskan bahwa usia adalah usia individu yang terhitung mulai seseorang saat dilahirkan sampai seseorang tersebut berulang tahun. Semakin cukup usia, tingkat kematangan dan kekuatan seseorang akan lebih matang dalam berfikir maupun bekerja.

Usia ibu yang muda (dewasa awal) pada umumnya dalam mencerna sebuah informasi yang didapatkan lebih mudah atau lebih baik. Ibu yang berusia lebih muda atau ibu yang baru mempunyai anak biasanya cenderung lebih memberikan perhatiannya kepada anaknya terutama tentang kesehatan anak yaitu pemberian imunisasi dasar (Prihanti dkk., 2016). Hal ini dikarenakan seseorang yang mempunyai usia produktif atau usia yang sudah matang akan mempunyai pola pikir yang lebih rasional yaitu semakin bertambahnya usia seseorang maka semakin matang pula dalam berfikir dan juga pengetahuan yang dimiliki akan lebih baik (Aprilia dkk., 2018).

Hasil penelitian dilokasi penelitian bahwa masih terdapat 11 responden (ibu) yang patuh dalam pemberian imunisasi difteri pada usia > 35 tahun. Peneliti berasumsi bahwa dengan peningkatan usia ibu juga dapat mempengaruhi kepatuhan ibu dalam pemberian imunisasi. Hal ini dikarenakan usia ibu yang lebih tua atau mengalami peningkatan ini dalam pengalaman mengurus anak atau mengasuh anak lebih tahu sehingga dapat mencegah atau menanggulangi terjadinya penyakit yaitu dengan memberikan imunisasi kepada anaknya. 
Peneliti berasumsi bahwa hubungan antara tingkat pendidikan kematangan usia ibu juga ibu dalam melaksanakan imunisasi ( $p$ menyebabkan bertambahnya value $=0,428)$.

informasi yang didapat maka akan semakin bertambah pula hal yang dilakukan sehingga mempertinggi wawasannya. Maka dari itu faktor usia tidak dapat berdiri sendiir karena usia dapat dipengaruhi oleh beberapa indiktaor yaitu tingkat pendidikan serta informasi yang didapat dari penyuluhan, lingkungan sekitar maupun media lainnya agar menimbulkan pengetahuan yang baik serta sikap yang positif.

Tabel 3

Hubungan Tingkat Pendidikan dengan Kepatuhan

\begin{tabular}{ccccccccc}
\hline \multirow{2}{*}{$\begin{array}{c}\text { Pendidik } \\
\text { an }\end{array}$} & $\begin{array}{l}\text { Tidak } \\
\text { Patuh }\end{array}$ & \multicolumn{2}{c}{ Patuh } & & Total & $\begin{array}{c}\mathrm{p}- \\
\text { Value }\end{array}$ & $\begin{array}{c}\text { OR } \\
(95 \% \\
\text { CI })\end{array}$ \\
\cline { 2 - 7 } & $\mathrm{n}$ & $\%$ & $\mathrm{n}$ & $\%$ & $\mathrm{n}$ & $\%$ & & \\
\hline Rendah & 13 & 81, & 1 & 20,3 & 2 & 33, & & 16,972 \\
& & $3 \%$ & 2 & $\%$ & 5 & $3 \%$ & & $(4,159$ \\
\hline Tinggi & 3 & 18, & 4 & 79,7 & 5 & 66, & 0,000 & - \\
& & $8 \%$ & 7 & $\%$ & 0 & $7 \%$ & & 69,265 \\
\hline Total & 16 & 100 & 5 & 100 & 7 & 100 & & \\
& & $\%$ & 9 & $\%$ & 5 & $\%$ & & \\
\hline
\end{tabular}

Penelitian ini sependapat terhadap penelitian Yuliana dan Sitorus (2018) bahwa ada hubungan antara tingkat pendidikan ibu dengan pemberian imunisasi dasar lengkap ( $p$ value $=$ 0,003). Tetapi penelitian ini berlawanan dengan penelitian Chabibah, Hastuti dan Handayani (2016) menyatakan bahwa tidak ada Penelitian lainnya juga menunjukkan bahwa semakin baik tingkat pendidikan ibu, maka akan semakin kritis/responsif dalam perkembangan keadaan lingkungan dan akan mengikuti perubahan tersebut serta akan semakin berkembang wawasan sehingga ibu dapat terdorong menanggapi perkembangan yang baru terutama dalam kemauan ibu untuk memberikan imunisasi kepada anaknya. Tetapi tidak semua ibu berpendidikan rendah tidak 
memberikan imunisasi kepada anaknya, begitu juga sebaliknya tidak semua ibu berpendidikan tinggi akan memberikan imunisasi kepada anaknya (Yuliana \& Sitorus, 2018).

Hasil penelitian dilokasi penelitian menunjukkan bahwa terdapat 12 responden dengan pendidikan rendah tetapi patuh dalam pemberian imunisasi DPT. Hal ini terjadi bahwa pendidikan ibu yang rendah rendah ini juga mampu memiliki informasi lebih mengenai imunisasi. Karena informasi tidak selalu diperoleh dari pendidikan formal tetapi juga dapat diperoleh dari pendiidkan non formal seperti melalui penyuluhanpenyuluhan yang dilakukan kader atau petugas kesehatan dan juga melalui media elektronik serta lingkungan sekitar.

Peneliti berasumsi bahwa pendidikan sangat memiliki pengaruh secara langsung terhadap perilaku seseorang dalam melakukan sesuatu hal seperti pemberian imunisasi DPT kepada anaknya karena dengan pendidikan yang tinggi, seseorang akan mampu lebih mudah mendapatkan informasi serta mengaplikasikan informasi tersebut untuk bertindak. Semakin tingginya pendidikan seseorang juga kadang tidak berpengaruh terhadap perilakunya seperti tidak memberikan imunisasi pada anaknya dari hasil penelitian terdapat 3 responden, hal ini dikarenakan dari faktor kepercayaan maupun dukungan contohnya ibu yang merasa bahwa imunisasi hanya membuat anaknya rewel serta tidak diperbolehkan oleh anggota keluarganya.

Tabel 4

Hubungan status pekerjaan dengan Kepatuhan

\begin{tabular}{|c|c|c|c|c|c|c|c|c|}
\hline $\begin{array}{c}\text { pekerjaa } \\
n\end{array}$ & $\begin{array}{l}\text { Tidak } \\
\text { Patuh }\end{array}$ & & atuh & & Total & & $\begin{array}{c}\mathrm{p}- \\
\text { Value }\end{array}$ & $\begin{array}{c}\text { OR } \\
(95 \% \\
\text { CI })\end{array}$ \\
\hline & $\mathrm{n}$ & $\%$ & $\mathrm{n}$ & $\%$ & $\mathrm{n}$ & $\%$ & \multirow{4}{*}{0,003} & \multirow{4}{*}{$\begin{array}{c}6,83 \\
3 \\
(1,9 \\
38- \\
24,0 \\
90)\end{array}$} \\
\hline Bekerja & 12 & 75 & $\begin{array}{l}1 \\
8\end{array}$ & 30,5 & $\begin{array}{l}3 \\
0\end{array}$ & 40 & & \\
\hline $\begin{array}{c}\text { Tidak } \\
\text { Bekerja }\end{array}$ & 4 & 25 & $\begin{array}{l}4 \\
1\end{array}$ & 69,5 & $\begin{array}{l}4 \\
5\end{array}$ & 60 & & \\
\hline Total & 16 & 100 & $\begin{array}{l}5 \\
9\end{array}$ & 100 & $\begin{array}{l}7 \\
5\end{array}$ & $\begin{array}{c}10 \\
0\end{array}$ & & \\
\hline
\end{tabular}

Hasil penelitian ini sesuai dengan penelitian Yuliana dan Sitorus (2018) bahwa ada hubungan antara status pekerjaan ibu dengan pemberian imunisasi dasar lengkap ( $p$ value $=$ 0,002). Tetapi penelitian ini berlawanan terhadap penelitian Hudhah dan Hidajah (2017) menyatakan bahwa tidak ada hubungan antara status pekerjaan ibu 
dalam imunisasi dasar lengkap (p value $=0,592)$.

Penelitian yang sudah dilakukan oleh peneliti menunjukkan bahwa status pekerjaan yang tidak bekerja paling banyak ditemukan pada kelompok imunisasi DPT yang patuh sebanyak 75 responden (93\%). Sehingga ibu yang tidak bekerja akan memberikan imunisasi kepada anaknya dibandingkan pada ibu yang bekerja. Apabila pada ibu yang bekerja sering kali berpengaruh terhadap ketidakpatuhan dalam mengimunisasikan anaknya karena kemungkinan pada saat pelayanan imunisasi dilakukan secara bersamaan dengan waktu bekerja atau ibu sibuk dengan pekerjaan lainnya sehingga lupa akan jadwal imunisasi (Yuliana \& Sitorus, 2018).

Penelitian lainnya menyatakan bahwa tidak semua status pekerjaan ibu yang bekerja tidak memberikan imunisasi kepada anaknya, begitu juga sebaliknya tidak semua status pekerjaan ibu yang tidak bekerja akan memberikan imunisasi kepada anaknya (Yuliana \& Sitorus, 2018). Hal ini didukung dari hasil penelitian dilokasi penelitian yang menunjukkan bahwa ibu yang bekerja juga memiliki peluang dalam memberikan imunisasi DPT pada anaknya sebanyak 18 responden karena adanya tingkat kemauan untuk memberikan imunisasi, pengetahuan ibu yang tinggi, sehingga pada saat ibu bekerja tetap memberikan waktu luangnya untuk memberikan imunisasi pada anaknya di posyandu atau di tempat pelayanan kesehatan lainnya serta ibu juga dapat meminta tolong kepada anggota keluarga untuk memberikan imunisasi di posyandu jika ibu sibuk bekerja.

Peneliti berasumsi bahwa pekerjaan juga mempengaruhi ibu terhadap pemberian imunisasi DPT, karena ibu yang tidak bekerja mempunyai waktu luang yang lebih banyak dibandingkan ibu yang bekerja untuk pemberian imunisasi DPT. Akan tetapi tidak semua ibu tidak bekerja memberikan imunisasi pada anaknya. Jadi, pekerjaan ini berkaitan juga dengan pengetahuan ibu yang tinggi tentang pentingnya imunisasi disertai kemauan ibu untuk mememberikan imunisasi serta dukungan keluarga 
terhadap imunisasi. Hal ini peneliti bisa membagikan saran pada para ibu dengan balita di RW 01 Kelurahan Kukusan Kecamatan Beji Kota Depok. Saran pada ibu yang bekerja ataupun ibu yang tidak bekerja harus memberikan imunisasi pada balitanya yaitu dengan cara mendatangi langsung ke pelayanan kesehatan seperti puskesmas atau rumah sakit ketika ibu tidak bekerja serta petugas kesehatan juga memberikan penyuluhan-penyuluhan agar ibu mau atau respon terhadap imunisasi DPT ini.

Tabel 5

Hubungan pengetahuan dengan Kepatuhan

\begin{tabular}{ccccccccc}
\hline $\begin{array}{c}\text { sengeta } \\
\text { penan } \\
\text { huan }\end{array}$ & $\begin{array}{l}\text { Tidak } \\
\text { Patuh }\end{array}$ & Patuh & & Total & $\begin{array}{c}\text { p- } \\
\text { Value }\end{array}$ & $\begin{array}{c}\text { OR } \\
(95 \% \\
\text { CI })\end{array}$ \\
\cline { 2 - 7 } & $\mathrm{n}$ & $\%$ & $\mathrm{n}$ & $\%$ & $\mathrm{n}$ & $\%$ & & \\
\hline Rendah & 11 & 68, & 1 & $22 \%$ & 2 & 24 & & 7,785 \\
& & $8 \%$ & 3 & & 4 & $\%$ & & $(2,29$ \\
\hline Tinggi & 5 & 31, & 4 & $78 \%$ & 5 & 76 & 0,001 & $1-$ \\
& & $3 \%$ & 6 & & 1 & $\%$ & & 26,45 \\
\hline Total & 16 & 100 & 5 & 100 & 7 & 10 & & $6)$ \\
& & $\%$ & 9 & $\%$ & 5 & $0 \%$ & & \\
\hline
\end{tabular}

Penelitian ini sependapat terhadap penelitian Yuliana dan Sitorus (2018) bahwa ada hubungan antara tingkat pengetahuan ibu dengan pemberian imunisasi dasar lengkap ( $p$ value $=$ 0,000). Begitu pula dengan penelitian Senewe, Rompas dan Lolong (2017) bahwa tingkat pengetahuan ibu berhubungan dengan kepatuhan ibu dalam pemberian imunisasi dasar $(p$ value $=0,012$ ). Tetapi penelitian ini bertentangan dengan penelitian Chabibah, Hastuti dan Handayani (2016) menyatakan bahwa tidak ada hubungan antara tingkat pengetahuan ibu dengan kepatuhan ibu dalam melaksanakan imunisasi $(p$ value $=$ 0,721).

Pengetahuan seseorang berkaitan dengan tingkat pendidikannya. Tingkat pendidikan ibu yang baik, maka semakin baik pula tingkat pengetahuan ibu. Selain pendidikan, faktor lainnya yaitu penyuluhanpenyuluhan dari tenaga kesehatan, media massa, media elektronik seperti internet maupun pengalaman pribadi juga dapat meningkatkan pengetahuan ibu (Senewe, Rompas \& Lolong, 2017).

Pengetahuan ibu juga dapat menentukan seseorang dalam mengambil sebuah keputusan terutama untuk melaksanakan pemberian imunisasi DPT/HB-HiB. Karena semakin tinggi tingkat pengetahuan ibu tentang imunisasi DPT/HB-HiB, maka semakin 
meningkat pula perannya sebagai pengambil keputusan seperti dalam kelengkapan imunisasi dasar (Yunizar \& Hadi, 2018). Hal ini juga dapat dikaitkan dengan faktor usia ibu, karena dengan usia yang muda atau usia produktif akan mudah dalam mendapatkan suatu pembelajaran mengenai imunisasi dan lebih mengutamakan kesehatan anaknya sehingga dapat meningkatkan wawasan sang ibu (Hudhah \& Hidajah, 2017).

Hasil penelitian dilokasi penelitian yaitu alasan ibu tidak memberikan imunisasi DPT yaitu ibu takut akan memberikan imunisasi karena setelah diberikan anaknya mengalami sakit/demam, ibu juga tidak percaya bahwa imunisasi memberikan manfaat karena tanpa imunisasi anaknya tetap sehat dan juga tidak mendapatkan dukungan dari anggota keluarga serta ibu juga sibuk bekerja sehingga tidak mempunyai waktu luang.

Peneliti berasumsi bahwa pengetahuan ibu tinggi didasari dari pendidikan ibu juga tinggi karena akan mudah dalam menerima informasi-informasi tambahan dari penyuluhan-penyuluhan, media massa maupun media elektronik.

\section{Tabel 6}

Hubungan Sikap dengan Kepatuhan

\begin{tabular}{|c|c|c|c|c|c|c|c|c|}
\hline \multirow{3}{*}{ sikap } & Tidak & \multicolumn{2}{|c|}{ Patuh } & \multicolumn{3}{|c|}{ Total } & \multirow{3}{*}{$\begin{array}{c}\mathrm{p}- \\
\text { Value }\end{array}$} & \multirow{3}{*}{$\begin{array}{c}\text { OR } \\
(95 \% \\
\text { CI }) \\
\end{array}$} \\
\hline & & & & & & & & \\
\hline & $\mathrm{n}$ & $\%$ & $\mathrm{n}$ & $\%$ & $\mathrm{n}$ & $\%$ & & \\
\hline \multirow[t]{2}{*}{ Negatif } & 12 & 75 & 1 & 25,4 & 2 & 36 & \multirow{5}{*}{0,001} & 8,800 \\
\hline & & $\%$ & 5 & $\%$ & 7 & $\%$ & & $(2,46$ \\
\hline \multirow[t]{2}{*}{ Positif } & 4 & 25 & 4 & 74,6 & 4 & 64 & & $1-$ \\
\hline & & $\%$ & 4 & $\%$ & 8 & $\%$ & & 31,47 \\
\hline Total & 16 & 100 & 5 & 100 & 7 & 10 & & 1) \\
\hline
\end{tabular}

Penelitian ini sependapat terhadap penelitian Yuliana dan Sitorus (2018) bahwa ada hubungan antara sikap ibu dengan pemberian imunisasi dasar lengkap $(p$ value $=0,000)$. Tetapi penelitian ini berlawanan terhadap penelitian Prihanti, dkk. (2016) menyatakan bahwa tidak ada hubungan antara sikap ibu dengan status kelengkapan imunisasi dasar $(p$ value $=0,057)$.

Sikap merupakan reaksi atau respon seseorang untuk bertindak terhadap suatu stimulus atau objek serta kesiapan atau kesediaan untuk melakukan sesuatu (Yunizar \& Hadi, 2018). Berdasarkan Teori Alport menyebutkan bahwa sikap memiliki 3 komponen yaitu kepercayaan (keyakinan), ide dan konsep terhadap 
objek, kehidupan emosional atau evaluasi terhadap suatu objek serta kecenderungan untuk bertindak (Notoatmodjo, 2012). Sehingga faktor sikap ini tidak dapat berdiri sendiri, ada faktor lain dapat mendukung dalam terjadinya sikap yaitu pengetahuan, pikiran, keyakinan (kepercayaan) serta emosi. Kepercayaan ibu diperoleh dari pengalaman pribadi dan dorongan orang lain karena kepercayaan didapatkan dari apa yang dilihat, diketahui dan sumber informasi maupun dorongan dari orang-orang terdekat seperti keluarga maka akan bersikap positif. (Zen, Rohita \& Sopiah, 2019).

Penelitian Yuliana dan Sitorus (2019) menyatakan kriteria ibu yang bersikap negatif seperti ibu yang tidak ada kemauan untuk memberikan imunisasi, ibu yang tidak percaya bahwa imunisasi bermanfaat, ibu yang memiliki pengetahuan yang rendah, ibu takut karena setelah diimunisasi akan sakit/demam, ibu merasa anaknya pada sehat walau tidak diimunisasi dan ibu juga tidak mendapat dukungan dari anggota keluarga.
Hasil penelitian dilokasi penelitian yaitu terdapat 15 responden yang bersikap negatif tetapi memberikan imunisasi DPT pada anaknya karena adanya dorongan atau ajakan dari tetangga maupun kader setempat sehingga ibu tidak bisa menolak sehingga ibu juga merasa perlu memberikan imunisasi, selain itu juga dapat dikarenakan faktor dorongan dari anggota keluarga sehingga ibu tidak bisa menolak keputusan seseorang yang lebih tua dari dirinya sehingga hal ini terjadi karena faktor lingkungan sekitar yang memberikan dukungan kepada sang ibu. Tetapi juga terdapat 4 responden yang bersikap positif tetapi tidak memberikan imunisasi DPT pada anaknya karena mereka beranggapan bahwa tanpa imunisasi anaknya tetap sehat dan mereka takut anaknya akan mnegalami demam setelah diimunisasi.

Hal ini membuat peneliti berasumsi bahwa sikap dapat mempengaruhi kelengkapan imunisasi DPT, karena ibu yang memiliki sikap positif biasanya memiliki tingkat pendidikan dan pengetahuan yang tinggi mengenai imunisasi yang 
dapat diperoleh dari sumber informasi seperti media massa atau elektronik maupun penyuluhanpenyuluhan dari petugas kesehatan dan ibu dengan sikap positif akan memberikan balitanya imunisasi lengkap agar bayinya mencapai tumbuh kembang yang optimal dan dapat terhindar dari berbagai penyakit. Sehingga kriteria ibu yang bersikap negatif seperti ibu yang tidak percaya terhadap imunisasi, ibu yang memiliki pengetahuan kurang dan ibu yang berfikir imunisasi hanya membuat anaknya sakit seperti demam. Sedangkan kriteria ibu yang bersikap postitif seperti ibu yang percaya akan manfaat dari imunisasi, pengetahuan yang baik sehingga tahu akibat dari tidak imunisasi, mendapatkan dorongan dari lingkungan sekitar dan ibu yang memiliki kemauan diri sendiri terhadap program imunisasi.

Tabel 7

Hubungan Kepercayaan dengan Kepatuhan

\begin{tabular}{ccccccccc}
\hline \multirow{2}{*}{$\begin{array}{c}\text { Keperca } \\
\text { yaan }\end{array}$} & $\begin{array}{l}\text { Tidak } \\
\text { Patuh }\end{array}$ & Patuh & & Total & $\begin{array}{c}\text { p- } \\
\text { Value }\end{array}$ & $\begin{array}{c}\text { OR } \\
(95 \% \\
\text { CI })\end{array}$ \\
\cline { 2 - 7 } & $\mathrm{n}$ & $\%$ & $\mathrm{n}$ & $\%$ & $\mathrm{n}$ & $\%$ & & \\
\hline Tidak & 9 & 56, & 1 & 16,9 & 1 & 25, & & 6,300 \\
Percaya & & $3 \%$ & 0 & $\%$ & 9 & $3 \%$ & & $(1,89$ \\
\hline Percaya & 7 & 43, & 4 & 83,1 & 5 & 74, & 0,003 & $9-$ \\
& & $8 \%$ & 9 & $\%$ & 6 & $7 \%$ & & 20,90 \\
\hline Total & 16 & 100 & 5 & 100 & 7 & 10 & & $1)$ \\
& & $\%$ & 9 & $\%$ & 5 & $0 \%$ & & \\
\hline
\end{tabular}

Penelitian ini sependapat terhadap penelitian Hudhah dan Hidajah (2017) bahwa ada hubungan antara kepercayaan ibu dengan pemberian imunisasi dasar lengkap ( $p$ value $=$ 0,000). Tetapi penelitian ini bertentangan dengan penelitian Izza, Lestari \& Tumaji (2017) menyatakan bahwa tidak ada hubungan antara kepercayaan ibu dengan pelaksanaan status imunisasi DPT ( $p$ value = $0,18)$.

Kepercayaan merupakan keyakinan seseorang yang dipengaruhi oleh pengetahuan seseorang dari keyakinan individu atupun lingkungan sekitar. Kepercayaan muncul dari sesuatu yang dilihat dan telah diketahui. Kepercayaan juga dapat terbentuk dari kurangnya mendapatkan sebuah informasi (Nurbaeti Zen, Rohita \& Sopiah, 2019).

Pengalaman buruk yang pernah dialami ibu dapat dijadikan sumber kepercayaan ibu sehingga dapat memutuskan untuk memberikan imunisasi pada anaknya (Hudhah \& Hidajah, 2017). Adapun kepercayaan masyarakat bahwa imunisasi dapat 
menyusahkan dan sesudah diberikan imunisasi pasti datang problem seperti masyarakat percaya bahwa setelah diimunisasi DPT bisa panas. Hal ini dikaitkan oleh keagamaan seseorang (Izza, Lestari \& Tumaji, 2017).

Hasil penelitian di lokasi penelitian menunjukkan terdapat 7 responden yang percaya tetapi tidak patuh dalam pemberian imunisasi DPT secara lengkap karena imunisasi dapat menimbulkan demam setelahnya serta ibu beranggapan anaknya pada sehat walau tidak diimunisasi secara lengkap, selain itu juga dikarenakan tidak mendapat dukungan dari anggota keluarga terhadap pemberian imunisasi. Akan tetapi, terdapat 10 responden yang tidak percaya tetapi patuh dalam pemberian imunisasi DPT secara lengkap karena awalnya mempercayai imunisasi baik untuk kesehatan tetapi dengan isu yang beredar membuat ibu menjadi tidak mempercayai imunisasi, selan itu banyak orang tua yang membawa cucunya untuk berimunisasi saat ibu bekerja atau tidak mengetahuinya dan mendapatkan masukan dari lingkungan sekitar bahwa perlu anak diberikan imunisasi sehingga ibu merasa mempercayainya.

Peneliti berasumsi bahwa kepercayaan seseorang terjadi dari keyakinan seseorang terhadap sebuah kegiatan tertentu seperti pemberian imunisasi. Seseorang beranggapan bahwa imunisasi memiliki efek samping yang dapat membuat adanya gejala KIPI setelah disuntik. Adapun cara berfikir seseorang yang berbedabeda yang dapat menghambat ibu untuk menuju yang lebih baik lagi seperti yang sudah dijelaskan sebelumnya yang membuat masyarakat bimbang untuk memberikan imunisasi pada anaknya. Padahal imunisasi juga memiliki manfaat yang sangatlah penting untuk mencegah terjadinya penyakit yang dapat dicegah dengan imunisasi (PD3I). Selain itu juga dapat diketahui bahwa faktor yang dapat mempengaruhi ibu untuk percaya atau tidak percaya terhadap imunisasi DPT yaitu faktor dukungan keluarga, pengetahuan, sikap positif serta pengalaman pribadi maupun keyakinan diri sendiri mengenai sesuatu hal untuk bertindak. 
Tabel 8

Hubungan Dukungan Keluarga dengan

Kepatuhan

\begin{tabular}{|c|c|c|c|c|c|c|c|c|}
\hline $\begin{array}{c}\text { Dukung } \\
\text { an }\end{array}$ & $\begin{array}{l}\text { Tidak } \\
\text { Patuh }\end{array}$ & & tuh & & Tota & & $\begin{array}{c}\mathrm{p}- \\
\text { Value }\end{array}$ & $\begin{array}{c}\text { OR } \\
(95 \% \\
\text { CI })\end{array}$ \\
\hline & $\mathrm{n}$ & $\%$ & $\mathrm{n}$ & $\%$ & $\mathrm{n}$ & $\%$ & \multirow{5}{*}{0,000} & \multirow{4}{*}{$\begin{array}{c}13,92 \\
9 \\
(3,46 \\
5- \\
55,99\end{array}$} \\
\hline Tidak & 13 & 81, & 1 & 23,7 & 2 & 36 & & \\
\hline $\begin{array}{l}\text { Menduk } \\
\text { ung }\end{array}$ & & $3 \%$ & 4 & $\%$ & 7 & $\%$ & & \\
\hline $\begin{array}{c}\text { Menduk } \\
\text { ung }\end{array}$ & 3 & $\begin{array}{l}18, \\
8 \% \\
\end{array}$ & $\begin{array}{l}4 \\
5 \\
\end{array}$ & $\begin{array}{c}76,3 \\
\% \\
\end{array}$ & $\begin{array}{l}4 \\
8 \\
\end{array}$ & $\begin{array}{l}64 \\
\% \\
\end{array}$ & & \\
\hline Total & 16 & $\begin{array}{c}100 \\
\%\end{array}$ & $\begin{array}{l}5 \\
9\end{array}$ & $\begin{array}{c}100 \\
\%\end{array}$ & $\begin{array}{l}7 \\
5\end{array}$ & $\begin{array}{l}10 \\
0 \%\end{array}$ & & 4) \\
\hline
\end{tabular}

Penelitian ini sejalan dengan penelitian Senewe, Rompas and Lolong (2017) bahwa ada hubungan antara dukungan keluarga dengan pemberian imunisasi dasar $(p$ value $=$ $0,000)$. Begitu pula dengan penelitian Yuliana dan Sitorus (2018) bahwa dukungan keluarga berhubungan dengan pemberian imunisasi dasar lengkap $(p$ value $=0,000)$.

Dukungan keluarga merupakan salah satu faktor terpenting untuk terwujudnya perilaku sehat. Bagian keluarga menganggap bahwa seseorang memiliki kepribadian yang mendorong akan selalu bersedia menerima jasa maupun bantuan jika sang ibu butuhkan (Senewe, Rompas \& Lolong, 2017). Keluarga juga menjadi awal memberikan dorongan atau support yang sangat berarti pada ibu terutama dalam memanfaatkan fasilitas kesehatan (Yuliana \& Sitorus, 2018).

Hasil penelitian dilokasi penelitian menunjukkan bahwa terdapat 3 responden yang mendapatkan dukungan keluarga yang mendukung dan tidak patuh ibu dalam pemberian imunisasi DPT karena ibu beranggapan dengan pemberian imunisasi 2 kali cukup untuk pencegahan serta tanpa imunisasi pun anaknya tetap sehat, selain itu juga karena ibu kasihan melihat anaknya demam setelah diimunisasi sehingga hal ini keluarga menyetujui sikap yang dilakukan ibu. Akan tetapi juga terdapat 14 responden yang tidak mendapatkan dukungan keluarga tetapi patuh dalam pemberian imunisasi DPT karena ibu merasa perlu untuk memberikan imunisasi, ibu percaya imunisasi dapat sebagai pencegahan terhadap penyakit. Selain itu dapat dipengaruhi dari pengetahuan keluarga mengenai imunisasi, karena semakin tinggi pengetahuan keluarga maupun ibu dapat mempengaruhi sikap atau dukungan terhadap imunisasi itu sendiri. 
Peneliti berasumsi bahwa dukungan keluarga sangatlah penting terhadap kelengkapam imunisasi DPT terutama peran keluarga yaitu suami. Hal itu karena suami sangat penting bagi ibu dalam mendukung tindakan ibu dalam memanfaatkan pelayanan kesehatan terutama pemberian imunisasi DPT. Karena dalam keluarga yang membuat keputusan adalah suami, ketika suami tidak mendukung kegiatan imunisasi DPT maka ibu tidak akan memberikan imunisasi kepada anaknya begitu pula sebaliknya ketika suami mendukung kegiatan imunisasi DPT maka ibu akan memberikan imunisasi kepada anaknya. Hal ini terjadi karena sang suami beranggapan bahwa tugas seorang suami hanya mencari nafkah dan memikirkan bagaimana agar kebutuhan bayi terpenuhi, padahal seorang ibu membutuhkan dukungan yang sangat besar dari suami.

Dengan pemberian dukungan yang tinggi akan menunjukkan keluarga menyadari bahwa sang ibu membutuhkan dukungan atau kehadiran dari keluarga. Hal ini juga dapat dipengaruhi pengetahuan yang dimiliki oleh anggota keluarga, karena semakin tinggi pengetahuan anggota keluarga akan semakin meningkat juga untuk mengambil keputusan yang baik seperti memberikan imunisasi pada anaknya untuk sebagai pencegahan terhadap penyakit.

\section{KESIMPULAN DAN SARAN}

Berdasarkan hasil analisis data dan pembahasan yang telah dilakukan, maka dapat peneliti menyimpulkan bahwa hasil analisis statistik menunjukkan bahwa faktor-faktor yang mempengaruhi kepatuhan ibu dalam pemberian imunisasi difteri pada balita meliputi usia ibu, tingkat pendidikan ibu, status pekerjaan ibu, pengetahuan ibu, sikap ibu, kepercayaan ibu dan dukungan keluarga.

Saran untuk penelitian selanjutnya adalah perlunya pemberian intervensi pedidikan kesehatan tentang imunisasi difteri

\section{DAFTAR PUSTAKA}

Aprilia, R. dkk. (2018). Hubungan Pengetahuan Dengan Sikap Ibu Tentang Imunisasi Difteri Pada 
Anak Balita Di Desa Jatiwates

Kecamatan Tembelang

Kabupaten Jombang, Nurse and

Health: Jurnal Keperawatan, Vol. 7, no. 1, Juli 2018, diakses tanggal 16 Februari 2019 http://ejournal-

kertacendekia.id/index.php/jnh/3 $0 / 33$

Chabibah, N., Hastuti, P. \& Handayani, M. (2016). Analisis Faktor yang Mempengaruhi Kepatuhan Ibu dalam Melaksanakan Imunisasi Di Posyandu Gading Sehat Surabaya, Riset Akuntansi Going Concern, Vol. 11, no.1, diakses tanggal 19 Februari 2019 http://e-journal-

stikeshangtuahsurabaya.ac.id/ind ex.php/JIK/article/view/37.

Dharma, K. K. (2011) Metodologi Penelitian Keperawatan. 1st edn., TIM, Jakarta.

Dinkes Jawa Barat (2016) Profil Kesehatan Jawa Barat 2016, Dinas Kesehatan Jawa Barat, Jawa Barat.
Dinkes Kota Depok (2017) Profil Kesehatan Kota Depok 2017, Dinas Kesehatan Kota Depok, Depok.

Hartoyo, E. (2018). Difteri pada Anak, Sari Pediatri, Vol. 19, no.5, Februari 2018. diakses tanggal 20 Februari 2019 https://saripediatri.org/index.php /sari-

pediatri/article/download/1332/p df.

Hudhah, M. \& Hidajah, A. C. (2017). Perilaku ibu dalam imunisasi dasar lengkap di Puskesmas Gayam Kabupaten Sumenep', Jurnal Promkes, Vol. 5, no.2, Desember 2017, diakses tanggal 19 Februari 2019 https://ejournal.unair.ac.id/PROMKES/a rticle/view/7737

Infodatin Kemenkes RI (2014), Kondisi Pencapaian Program Kesehatan Anak Indonesia, Pusat Data dan Informasi, Jakarta.

Izza, N., Lestari, D. \& Tumaji 
(2017), 'Faktor Orang Tua Dan

Status Imunisasi DPT Anak 12-

36 Bulan Di Kecamatan

Ketapang Dan Kecamatan

Sokobanah Kabupaten

Sampang', Buletin Penelitian

Sistem Kesehatan, Vol. 20, no.2,

Maret 2017, diakses tanggal 03

Maret 2019

http://ejournal.litabng.depkes.go.

id/index.php/hsr/article/viewFile /6958/4981

Kemenkes RI (2017), Ini Makna

KLB Difteri. Jakarta: Biro

Komunikasi dan Pelayanan

Masyarakat, KemenKes RI.

diakses tanggal 19 Februari 2019

http://www.depkes.go.id/article/

view/17121200001/ini-makna-

klb-difteri.html.

Kemenkes RI (2017). Profil

Kesehatan tahun 2017,

Kementrian Kesehatan Republik

Indonesia, Jakarta.

Kemenkes RI (2018), Pemerintah

Optimis KLB Difteri Bisa

Teratasi, Biro Komunikasi dan

Pelayanan Masyarakat, KemKes

RI, diakses 19 Februari 2019 www.depkes.go.id/article/view/1801

1500004/pemerintah-optimis-

klb-difteri-bisa-teratasi.html.

Masturoh, I. \& Anggita, N. (2018), Metodologi Penelitian

Kesehatan, Bahan Ajar Rekam

Medis dan Informasi Kesehatan

KemKes RI, Kementrian

Kesehatan RI, Jakarta.

Prihanti, G. S. dkk. (2016). FaktorFaktor Yang Mempengaruhi Status Kelengkapan Imunisasi Dasar Di Wilayah Kerja Puskesmas X Kota Kediri, Vol. 12, no.2, Mei 2018, diakses tanggal 03 Maret 2019 http://ejournal.umm.ac.id/index. php/sainmed/article/view/6644/0

Riskesdas (2018). Hasil Utama Riskesdas 2018. Riset Kesehatan Dasar, Jakarta.

Senewe, M. S., Rompas, S. \& Lolong, J. (2017) Analisis Faktor-Faktor Yang Berhubungan Dengan Kepatuhan Ibu Dalam Pemberian Imunisasi Dasar Di Puskesmas Tongkaina 
Kecamatan Bunaken Kota

Madya Manado', e-journal

Keperawatan, vol. 5, no. 1,

Februari 2017, diakses tanggal

29 Januari 2019

https://ejournal.unsrat.ac.id/inde

x.php/jkp/article/viewFile/14732 $/ 14300$.

United Nations (2015). Transforming our world: the 2030 agenda for sustainable development, Publikasi United Nations, diakses 03 Maret 2019

http://sustainabledevelopment.un .org

WHO (2017). Dyptheria Reprted Cases', Publikasi WHO, diakses tanggal 19 Februari 2019 http://apps.who.int?immunizatio n_monitoring?globalsummary?ti meseries?tsincidencediptheria.ht $\mathrm{ml}$.

Yuda, A. D. \& Nurmala, I. (2018) 'Hubungan Karakteristik, Pengetahuan, Sikap Dan Tindakan Ibu Dengan Kepatuhan Imunisasi', Jurnal Berkala Epidemiologi, Vol. 6, no. 1, Maret 2018, diakses tanggal $16 \quad$ Februari 201 https://e-

jourmal.unair.ac.id/JBE/article/d ownload/9482/5361

Yuliana \& Sitorus, S. (2018). Faktor Ynag Berhubungan Dengan Pemberian Imunisasi Dasar Lengkap Di Wilayah Kerja Puskesmas Medan Area, Jurnal Kesehatan Global, Vol. 1, no. 3, September 2018, diakses tanggal 19 Februari 2019 http://www.researchgate.net/pub lication/329601881_Faktor_yan g_Berhubungan_Dengan_Pembe rian_Imunisasi_Dasar_Lengkap_ di_Wilayah_Kerja_Puskesmas_ Medan_Area.

Yunizar, A. \& Hadi, A. J. (2018). Perilaku Ibu Dalam Pemberian Imunisasi DPT/HB-HIB Di Desa Sinabang Kecamatan Simeulu Timur. Jurnal Kesehatan Global, Vol. 1, no. 2, Mei 2018, diakses tanggal 19 Februari 2019 https://www.researchgate.net/pu blication/329606208_Perilaku_I bu_Dalam_Pemberian_Imunisas i_DPT/HB-

HIB_di_Desa_Sinabang_Kecam 
atan_Simeulu_Timur

Zen, Rohita \& Sopiah, S. (2019),

Hubungan Sikap Ibu yang Mempunyai Bayi dengan

Pelaksanaan Imunisasi DPT Di

Puskesmas Kawali Kabupten

Ciamis Tahun 2018', Jurnal

Kesehatan Galuh, Vol. 1, no.1, .

Januari 2019, diakses tanggal 03

Maret 2019

https://jurnal.unigal.ac.id/index.p

hp/JKG/article/download/1789/1

514 